\title{
FROM SECRET AGENTS TO INTERAGENCY
}

\author{
VINCIANE DESPRET
}

\begin{abstract}
Some scientists who study animals have emphasized the need to focus on the "point of view" of the animals they are studying. This methodological shift has led to animals being credited with much more agency than is warranted. However, as critics suggest, on the one hand, the "perspective" of another being rests mostly upon "sympathetic projection," and may be difficult to apply to unfamiliar beings, such as bees or even flowers. On the other hand, the very notion of agency still conveys its classic understanding as intentional, rational, and premeditated, and is still embedded in humanist and Christian conceptions of human exceptionalism. This paper seeks, in the first part, to investigate the practical link between these two notions and the problems they raise. In the second part, following the work of two historians of science who have revisited Darwin's studies of orchids and their pollinators, it will observe a shift in the meaning of the concept of agency. Indeed, creatures may appear as "secret agents" as long as we adopt a conventional definition of agency based on subjective experience and autonomous intention. However, when reframed in the terms of "agencement"-an assemblage that produces "agentivity"agency seems to be much more extensively shared in the living world. We will then explore some of the concrete situations in which these agencements are manifested, and through which creatures of different species become, one for another and one with another, companion-agents.
\end{abstract}

Keywords: animals, agency, perspective, agencement, co-evolution, affinities

"It matters what stories we tell to tell other stories with; it matters what concepts we think to think other concepts with."1

In recent years, some scholars working in the field of animal studies have reoriented their research by trying to take into account the "point of view" of the animals they observe. The studies originate mostly in primatology, but workers in other fields followed the trend with-among others-ravens, babblers, elephants, or even, surprisingly, sheep. ${ }^{2}$ Most of the scientists who adopted this

1. Donna Haraway, "Sowing Worlds: A Seed Bag for Terraforming with Earth Others," in Beyond the Cyborg: Adventures with Donna Haraway, ed. Margaret Grebowicz and Helen Merrick (New York: Columbia University Press, 2013).

2. For the ravens, see Bernd Heinrich, Mind of the Raven (New York: Harper Collins, 2000); for the babblers, Amotz Zahavi and Avishag Zahavi, The Handicap Principle: A Missing Piece of Darwin's Puzzle (Oxford: Oxford University Press, 1997); for the elephants, Cynthia Moss, Elephant Memories: Thirteen Years in the Life of an Elephant Family (Chicago: University of Chicago Press, 2000); and for the sheep, Thelma Rowell, “A Few Peculiar Primates," in Primate Encounters: Models of Science, Gender, and Society, ed. S. Strum and L. Fedigan (Chicago: University of Chicago Press, 2000), 57-71. Many others could be mentioned. 
new approach claimed that this methodology enabled them to better understand their animals, to give more reliable depictions, and led them to ask questions that matter for the animals. In the words of Shirley Strum, for example, trying to see the baboons from a "baboon's perspective" allowed her "to let the baboons themselves 'tell' me what was important."

One may note that still more recently, the attempt to take into account the point of view of animals has coincided with a political agenda: to credit animals with interests, will, preferences, and intentions that should be taken into account. In other words, adopting the perspective of a given animal should lead to its being credited with "agency."

"Perspective" and "agency" seem therefore to share, in this recent historical context, the same (political) stakes: on the one hand, "perspective" aims to "subjectify" the animals in the sense of "making a subject" - a subject having "interests" that should be protected or fulfilled. On the other hand, as Susan Crane interestingly reminded me, the term "agency" emerged especially in the 1970s as a term that encapsulated a critique of structuralism: structuralist analyses of culture did not recognize the consciously counter-hegemonic actions of individuals; structuralism did not account for the creative and subversive interventions that people can make even as their societies "make" them. But Crane also adds that we should be aware that the concept of agency is embedded in humanist and Christian versions of human exceptionalism. These creative and subversive interventions illustrate the classic understanding of agency as intentional, rational, and premeditated. ${ }^{4}$

We could extend this critique to the notion of perspective itself since this concept rests on an anthropocentric notion of subjectivity. As Lorraine Daston reminds us:

The language of perspective carries with it weighty assumptions about what it means to understand other minds. Within the model of a world divided up into the objective and the subjective, and armed with the method of sympathetic projection, understanding another mind could only mean seeing with another's eyes (or smelling with another's nose or hearing with another's sonar, depending of the species) - "put yourself in his place," as Lloyd Morgan titled one of his chapters. ... Here I can only hint at the several intellectual and cultural shifts that created the perspectival mode: the habit of interior observation cultivated by certain forms of piety; the increasingly refined language of individual subjectivity developed in the eighteenth- and nineteenth-century novel; the equation drawn between sensory experience and self by sensationalist psychology; political and economic individualism; the cult of sympathy, which expanded to embrace first children, then animals, and finally denizens of other times and places.... [Perspective] is not simply another form of subjectivity; it is the apotheosis of subjectivity as the essence of mind. ${ }^{5}$

In this article I want to investigate the links that have been created between these two concepts, "perspective" and "agency." In the first part, I would like to put this link to the test: does "being a subject," for an animal, lead to "being an agent"?

3. Shirley Strum, Almost Human (New York: Random House, 1987), 30.

4. Susan Crane, comment at conference.

5. Lorraine Daston, "Intelligences: Angelic, Animal, Human," in Thinking with Animals: New Perspectives on Anthropomorphism, ed. L. Daston and G. Mitman (New York: Columbia University Press, 2005), 53. 
Whether or not this is the case, what do these concepts mean in each case? In the second part, I will explore cases in which this link is made. My aim will be to ask whether there are practices and narratives that will let us shake free of the old categories of the agent as an autonomous rational actor and of the perspective as mere "sympathetic projection." 6

First, there are many ways to construct another "point of view." The first clear theorization of an animal's "point of view" appears in the work of naturalist Jakob von Uexküll (1864-1944). ${ }^{8}$ According to von Uexküll's theory-the Umwelt theory - animals only perceive things that have a meaning for them; things that have no meaning are not perceived. Moreover, the animal construes meanings in acting - a thing taking the meaning of the action that it renders possible - and this very thing therefore exists for this animal. According to von Uexküll, scientists may make an inventory of what makes animals act and react, whether they react or not, and how: they may therefore infer what the animals perceive and what the perceived things mean for them.

Von Uexküll did not so much aim to adopt the animal perspective. Rather, in collecting "meanings," he wanted to rebuild the world as each animal perceives it, to populate this world with all the things that exist for a given animal, and to identify the meaning all these things take for the animal. The paradigmatic example associated with his name is the tick, whose world is composed of only a few phenomena: the smell of the butyric acid, the heat of the mammal's body, the tasting of a warm liquid (the blood of the victim), and the feeling of the fur. I like to translate von Uexküll's proposal with the words of the cognitive ethologist Mark Bekoff - a tick is a way of knowing the world ${ }^{9}$ - and to think of our world as constituted of an infinite series of different ways of knowing, feeling, and being affected.

Still, according to von Uexküll, the possibility for an animal to have/to build its own world, and to give meanings to things, leads to the possibility that the animal might become a real "subject," the "author" of its own perceptions and meanings. This possibility opens the path for a more active conception of the animal. If perception is to be "pathos," this pathos, however, does not imply passivity; rather, it testifies to an active endeavor that fills the world with meaningful objects and beings.

Von Uexküll, directly or more often indirectly, had marked influence on the field. For example, French historian Eric Baratay's beautiful book contains a potentially fruitful development of his proposal. For a history of animals to be

6. This also means, for me, to escape from the relentless accusations of anthropomorphism that have always pervaded the debates around the question of perspective.

7. See, for example, Temple Grandin's work, and for a very interesting version of her approach, see Erica Fudge's paper in this issue: "Milking Other Men's Beasts," History and Theory, Theme Issue 52 (2013), 13-28.

8. Jakob von Uexküll, A Foray into the Worlds of Animals and Humans (with A Theory of Meaning), transl. Joseph O’Neil ( Minneapolis: University of Minnesota Press, 2010).

9. Mark Bekoff, “Animal Passions and Beastly Virtues: Cognitive Ethology as the Unifying Science for Understanding the Subjective, Emotional, Empathic, and Moral Lives of Animals," Zigon 41 , no. 1 (2006), 74 . 
possible, the historian should take the risk of speculating: how did animals understand and experience what humans offered them or forced on them? ${ }^{10}$

The fate of von Uexküll's proposal was, however, less promising than one might have expected among scientists whom he influenced. Konrad Lorenz, for example, certainly made great efforts to enter animals' minds. ${ }^{11}$ But we have to observe, as sociologist Eileen Crist notes, that this did not prevent him from "objectifying" animals with the instinct theory. In brief, as Crist writes,

ethologists use a technical vocabulary, in part constructed by themselves and in part appropriated from behaviorist psychology. The linguistic and argumentative edifice created by the pioneer ethologists led to the representation of animals as natural objects. Yet it is quite certain that neither Tinbergen nor Lorenz wanted to "desubjectify" animals. ${ }^{12}$ In using a technical, highly theoretical language, they aimed to establish the study of animal behavior as a rigorous science; they presupposed a specific idea of "science," on the model of natural science as well as of comparative psychology.... The inexorable if unwitting consequence of applying a technical language was the epistemological objectification of animals and ultimately their mechanomorphic portrayal. ${ }^{13}$

Crist quotes, to illustrate the contrast between this mode of theorization and a more "naturalistic" one, the story Darwin tells about a peacock "that wanders the path of appropriate seduction." The peacock, Darwin continues, "may sometimes perform in front of grouse or even stranger animals." But this rather counterproductive behavior from the point of view of natural selection nevertheless finds its legitimation outside the realm of useful behaviors: the peacock, Darwin explains, "evidently wishes for a spectator of some kind, and will shew off his finery, as I have often seen, before poultry or even pigs. All naturalists who have closely attended to the habits of birds . . . are unanimously of opinion that the males delight to display their beauty. ${ }^{14}$ "All naturalists," indeed, provided we confine our scope to the nineteenth century. This depiction takes a radically different shape when told from a classical-ethological standpoint in the mid-twentieth: the displays become "'fixed action patterns,' that is, innately given behavioral patterns with certain 'inner specific energies' associated with them. The behavioral pattern . . . is released by the appropriate stimulus. . . . [If the latter] is absent for a long enough period, the inner specific energies accumulate and can finally trigger . . . in the face of a minimal, inappropriate stimulus . . . the expression of the behavioral pattern." 15 In this case, the responses go off "in vacuo." "In vacuo" means here a chicken or a pig.

For Darwin, it seems obvious that the bird is so vividly fixated on the fact that the display is for showing his beauty that the peacock himself decontextualizes the action from its proper occasion. According to Crist, in Darwin's portrayal,

10. Eric Baratay, Le point de vue animal: Une autre version de l'histoire (Paris: Seuil, 2012). But see, again, Fudge's paper for the difficulties of this stance.

11. Konrad Lorenz, "Companionship in Bird Life" in Instinctive Behavior, ed. C. H. Schiller and K. S. Lashley (New York: International University Press, 1957).

12. But see, for a more radical criticism, Marion Thomas, "Rethinking the History of Ethology: French Animal Behaviour Studies in the Third Republic (1870-1940)." PhD dissertation, Center for the History of Science, Technology and Medicine," University of Manchester, 2003.

13. Eileen Crist, Images of Animals (Philadelphia: Temple University Press, 1999), 89.

14. Ibid., 112 .

15. Ibid., 114. 
the peacock gains agency "as inhabitant of an aesthetic and exhibitionist world" in which he is the author of his action. ${ }^{16}$ By contrast, she remarks, in classical ethological depictions, the bird is oblivious to the meaning of his actions. The technical terms and their logical connections account for a behavior that is not performed by an agent, but that "happens" to it. In the one case, the animal acts (even ridiculously, Crist says, but from which point of view?); in the other, it is acted upon by some drive over which it has no control. The difference between the two descriptions is parallel to von Uexküll's distinction between a dog and an sea urchin: "when a dog runs, the animal moves its legs, when a sea urchin runs, the legs move the animal."17

According to this latter contrast, it appears that being a subject does not equal being an agent. In other words, taking into account the perspective of another animal may make agency perceptible - may make it particularly salient, or even enhance it-as much as it may not. The dog is both subject and agent, whereas the urchin is solely a subject. This may confirm Crane's criticism: to be an agent seems to be still entangled in the classic understanding of agency as intentional, rational, and premeditated.

The peacock, however, may be both subject and agent in Darwin's description, though he is devoid of agency in classical ethological discourse. This leads me to underscore another dimension of the situation: not only is the peacock without any form of agency, but so is the pig, itself being lost "in vacuo." If the gaze of a pig may matter for an exhibitionist peacock, why shouldn't one take into account (and what prevents one from taking into account) the fact that the pig, a notoriously curious and sensitive being, might have responded to the former, looked back at it, and might have been affected in such a way that affects the peacock in return? Why not imagine these two beings liberated from pure reproductive motives, and enjoying together an unprecedented, creative, improvised, and queer "becoming together"?

I propose to test the link between this proposal and a critique that parallels the reproach Crist addressed to classical ethology with its contrast between different narratives. In a beautiful article, mostly about orchids, their pollinators, and the scientists who study them, two historians of science, Carla Hustak and Natasha Myers, devoted their attention to the different ways in which naturalists have conceived and described the practices through which plants lure (what I would call) their "animal partners" to secure their fertilization. Hustak and Myers mostly compare Darwinian and neo-Darwinian contemporary approaches (that is, the approaches of sociobiologists). ${ }^{18}$ They remark that plants' and insects' behaviors, in sociobiological theories, are now grounded in deterministic models that reduce interactions among species to the actions of "selfish genes." These "selfish genes" are, according to these theories, geared to the task of reducing an organism's energy expenditure while maximizing its reproductive fitness for long-term species survival.

16. Ibid.

17. von Uexküll, in ibid., 76.

18. Carla Hustak and Natasha Myers, "Involutionary Momentum: Affective Ecologies and the Sciences of Plant/Insect Encounters," Différences 23, no. 3 (2012), 74-118. 
Many of the numerous species that comprise the Ophrys genus have the remarkable ability to lure pollinators in spite of the fact that they do not offer the insects a nectar "reward." Ophrys species can attract their pollinators selectively by exhaling volatile compounds that mimic the sex pheromones of the latter; these volatile compounds can elicit "typical" sexual behavior in male insects: male bees swarm, for example, around flowers, and expose their genitalia before landing.

In these models, Hustak and Myers write, it is generally claimed that in trying to mate with the flowers, the bees "inadvertently" participate in orchid fertilization. Chemical biologists claim that this strategy allows Ophrys orchids to "exploit" male insects' sexual proclivities for their own ends. Hustak and Myers remark that in these accounts orchids are figured as "frauds" involved in a "sexual swindle" (they quote the terms ecologists actually use). In this story, male insects" "innate behavioral responses" are exploited, and the insects are identified as "dupes" "that have fallen for a signal that fakes the scent of their conspecific females." 19

Citing these theories, Hustak and Myers continue, shows "how stories emerging in the field of chemical ecology today constrain narratives of interspecies relations along axes of deception and exploitation." These kinds of accounts "reduce the complex relations between orchids and insects in a way that stultifies both orchid and insect agency and renders ecologies populated by blind, reactive automatons." ${ }^{20}$ They note a common characteristic of these narratives: any hint of interspecies intimacy is carefully policed. The event of pollination is a decidedly "asymmetrical" encounter; since Ophrys orchids offer no nourishment for visiting insects, the pollination event is not considered a mutually beneficial encounter; rather, it is a phenomenon engendered through a "unilateral adaptation" of the orchid to the bee. Mimicking orchids are the only participants reaping a benefit from the encounter; the insects are rendered passive compared to the wily plants. Hustak and Myers note that recent statements in the literature vociferously resist the term "co-evolution" to describe this phenomenon in Ophrys. Though imbued with the power to deceive, these plants are still conceived as mechanical actants: "their near-perfectly attuned aromatic chemistries are not cleverly concocted propositions; they are merely the blind effects of random genetic variation subject to the selective forces imposed by their pollinators. A neo-Darwinian economy, it seems, cannot admit pleasure, play, or improvisation within or among species."21 Plant ecology is thus rendered on a model of a militarized economy that structures life as a struggle in a war zone of competitors, enemies, dupes, and deceptive mimics.

The two authors instead suggest working "athwart the reductive, mechanistic, and adaptationist logics that ground the ecological sciences," and developing a reading that "amplifies accounts of the creative, improvisational, and fleeting practices through which plants and insects involve themselves in one another's

19. Hustak and Myers, "Involutionary Momentum," 76.

20. Ibid.

21. Ibid., 76-77. 
lives. ${ }^{22}$ Following others, ${ }^{23}$ they propose to supplement evolutionary logics with what they refer to as an involutionary mode of attention, an "affective ecology shaped by pleasure, play, and experimental propositions." ${ }^{24}$ In an "involutionary reading," the mimetic power of Ophrys's seductive scents need not be reduced to the outcome of the selective advantage of random mutations: "it is an effect and affect immanent to responsive, sensing, sentient bodies." 25

How do Hustak and Myers make agency exist? First, they seek it by searching for richer narratives. They seek descriptions that render the activity salient: for example, they quote Darwin on the sequence of actions performed by the flowers: Orchid tissues are, according to the latter, "excitable," "sensitive," or even "irritable," the plants could "actively alter their anatomies, twisting, turning, and torquing their forms in response to insect visitors." ${ }^{26}$ Darwin constructs narratives of encounters where both the flower and its companion-species (or should we say its companion-kingdoms?) are actively involved in each other's lives. For example, in his depiction of an insect foraging for nectar, he points out that an orchid would often actively deposit its pollinium somewhere on the insect's body; he also describes at length his observation of other flowers (from another species) that had imprisoned the visiting insect for half an hour.

One could suggest that Hustak and Myers re-enchant what has been disenchanted with narratives of "an inextricable web of affinities" (as Darwin himself formulated it), stories of connivances, attractions, reciprocal inductions, and also repulsions, that weave their own narratives in the web, and therefore create new connections and affinities. They focus our attention on a world rich in affects, full of beings able to affect and be affected by others, creatures "involving themselves

22. Ibid., 77 .

23. See, for example, the work of Scott Gilbert, who challenges the generally accepted view of "individuals." "Symbiosis is becoming a core principle of contemporary biology, and it is replacing an essentialist conception of 'individuality' with a conception congruent with the larger systems approach. ... We report here that the zoological sciences are . . finding that animals are composites of many species living, developing, and evolving together. The discovery of symbiosis throughout the animal kingdom is fundamentally transforming the classical conception of an insular individuality into one in which interactive relationships among species blur the boundaries of the organism and obscures the notion of essential identity." Scott F. Gilbert, Jan Sapp, and Alfred I. Tauber, " A Symbiotic View of Life: We Have Never Been Individuals," Quarterly Review of Biology 87, no. 4 (2012), 326. See also S. F. Gilbert, E. McDonald, N. Boyle, N. Buttino, L. Gyi, M. Mai, N. Prakash, and J. Robinson, "Symbiosis as a Source of Selectable Epigenetic Variation: Taking the Heat for the Big Guy," Proceedings of the Royal Society, London B., n. 365 (2010), 371-378.

24. Hustak and Myers, "Involutionary Momentum," 78. Hustak and Myers are inspired by Lynn Margulis's proposal. If all life shares the same ancestry, the concept that the tree is the right topology should be seriously challenged. According to Margulis (quoted by Hustak and Myers, "Involutionary Momentum," 96), "a tree assumes that the lineages continue to branch, and branch, and branch from a common ancestor." Margulis pointed to recent work that demonstrates the "movement of genetic material from one branch to another" and insisted that this movement "makes the topology a net, a web, and no longer a tree." If images of trees stand in for phylogeny, filial loyalty, and the defense of the family line, Margulis's endosymbiotic theory accounts for evolutionary innovation in the dense tangle of branches. The authors add: "If, as the Oxford English Dictionary reminds us, evolution is a 'rolling outwards,' a kind of speciation through divergence in the shape of branching trees, we approach involution as the 'rolling, curling, turning inwards' that brings distinct species together to invent new ways of life" (96).

25. Hustak and Myers, "Involutionary Momentum," 78.

26. Ibid., 86 . 
in one another's lives." ${ }^{27}$ But this is not enchantment, nor is it re-enchantment. This would imply that the world originally would have been non-enchanted, or previously disenchanted. What they did, instead, was to read Darwin before the disenchantment happens. As Bruno Latour suggests, the whole history of science shows how difficult it is to follow the emergence of any scientific concept "without taking into account the vast cultural background that allows scientists to first animate them, and then, but only later, to de-animate them. Although the official philosophy of science takes the last movement as the only important and rational one, just the opposite is true: animation is the essential phenomenon; de-animation a superficial, ancillary, polemical and more often than not a vindicatory one." ${ }^{28}$ Hustak and Myers did not have to re-enchant, they just had to carefully follow a scientist who did not de-animate the world he was observing. They carefully follow the practices through which Darwin himself became animated in an animating world, the practices through which he experimented with the flowers, taking the role (with his fingers of course) of the pollinator. They call for (and enact, since they are themselves actively involving their own practice) what Isabelle Stengers refers to as an"ecology of practices" among plants, insects, and the scientists who draw their intricate relations into view. ${ }^{29}$

They suggest, for example, that by inserting himself into the kinaesthetic and affective relations of insects and orchids, Darwin's experimental practice took on mimetic form. I, in turn, am tempted to make the assumption that taking mimetic form to involve oneself in the lives of other beings whose prodigious feats and whose relations actually rest upon mimicry cannot be reduced to mere empathy nor to a psychological process of identification that makes understanding possible. Rather, it is to get involved in the lives of other beings the very same way they get involved in the lives of one another. That is not only a gesture of mere imitation; it is to enter into the game of reciprocal induction. This creates a new connection in the web of "inextricable affinities," an "affine connection." ${ }^{30}$ It is to call for a response and to respond. It is not becoming like insects or flowers in a mimetic process (let us take seriously the concept of "affine" which refers to the limit of the web of kin, ad finitum ${ }^{31}$ ). It is becoming with them and (starting) from them. In other words, Darwin enters the historical game of co-evolution, a

27. Ibid., 83 .

28. Bruno Latour, "Which Language Shall We Speak with Gaia?" Lecture for the Holberg Prize Symposium 2013: "From Economics to Ecology," Bergen, Norway, June 4.

29. Isabelle Stengers, Cosmopolotics, transl. R. Bonomo (Minneapolis: University of Minnesota Press, 2010).

30. Donna Haraway speaks of "just-barely-affinities" or "partial-affinities": "The knowing self is partial in all its guises, never finished, whole, simply there and original; it is always constructed and stitched imperfectly, and therefore able to join with another, to see together without claiming to be another. Here is the promise of objectivity: a scientific knower seeks the subject position not of identity, but of objectivity: that is, partial connection." Haraway, "Situated Knowledges: The Science Question in Feminism and the Privilege of Partial Perspective," in Simians, Cyborgs and Women: The Reinvention of Nature (London: Free Association Books, 1991), 193.

31. The anthropologist Eduardo Viveiros de Castro reminds us that the affine is above all an Other, and is always mediated by a third term (for example, brother-in-law is always in reference to a sister). The affine is always connected "à la limite," "adfinitum." Eduardo Viveiros de Castro, "Perspectival Anthropology and the Method of Controlled Equivocation," Tipiti: Journal of the Society for the Anthropology of Lowland South America 2, no. 1 (2004), 3-22. 
game that undoes and redoes, a game that re-members the creatures that actively involve themselves in the process..$^{32} \mathrm{He}$ enacts as well as being enacted by new narratives, new assemblages, which in turn activate each of the beings involved, and involve more beings in a cascade of practices.

These narratives therefore challenge assumptions, not only, as Hustak and Myers claim, about bodily and species boundaries, but also about subject/agent boundaries. Who activates Darwin? The flower he touches? But who touches when one touches? Who may be said to initiate? Who may be said to act? Who may be said to call to act? The flowers? The human observer? The insects he substitutes for? The rereading the two historians offered to his work? But aren't they themselves activated by Darwin, touched by his practice and his writings, by the orchids, and by the pollinators? No one re-enchants the world, here. They just resist de-animating it, actively - or not.

Is the contrast we draw after von Uexküll-between the dog and the sea urchin - still relevant? Does agency rest upon the contrast between moving oneself and being moved? Between acting and being acted upon, between acting and reacting? On the one hand, plant biologists note that not all plants can be said to act like orchids. Heavy cultivation, for example, has disabled otherwise adept plants. They have been rendered "deaf" and "mute" through intensive agricultural practices and pesticide use. ${ }^{33}$ This means that agency may not be the effect of the sole practice of the scientist who describes (or of the subjectivity of the observer). What may be said for plants may also be said for animals. Agency can be gained, but it may also be impoverished or dramatically weakened. We should add that the problem we face with animals is not so much the contrast between dogs and sea urchins - not to mention the fact that this contrast probably does not make any sense for those who passionately study sea urchins and probably know that legs will never suffice to make them move-but between "charismatic animals" and those that, as Latour said, did not "get a chance," between those that have "articulated" successfully and those that have been poorly articulated. ${ }^{34}$

On the other hand, it seems that the contrast between the one who moves and the one who is moved might be too simple. This contrast is not articulate, nor does it articulate anything well. To address this question, I would suggest that we reread Gilles Deleuze's reading of von Uexküll. Let us remember that there isn't, in any animal's world, any object that can be said to be neutral, without any vital quality. Everything that exists for an organism is a sign that affects, or an affect that signifies. According to Deleuze, each object that is perceived effectuates a power to be affected. It is a "rapport of force." Each living being renders other creatures capable (of affecting and of being affected), and they are entangled in a myriad of rapports of forces, all which are "agencements." 35

32. In that sense, one may suggest that scientific practices of this kind engage scientists in the process of involution when they explore, with other organisms, new ways to live with and alongside one another, as they are enacting/transforming/inventing the very process they seek to describe.

33. Ian Baldwin, in Hustak and Myers, "Involutionary Momentum," 103.

34. See his comments about Thelma Rowell's work with sheep in Bruno Latour, "A Well Articulated Primatology: Reflections of a Fellow Traveler," in Primate Encounter: Models of Science, Gender, and Society, ed. S. Strum and L. Fedigan (Chicago: University of Chicago Press, 2001), 358-382.

35. Gilles Deleuze and Felix Guattari, A Thousand Plateaus: Capitalism and Schizophrenia, transl. B. Massumi (Minneapolis: Minnesota University Press, 1987), 260, 321. 
Deleuze's translator, Brian Massoumi, chose to translate agencements as "assemblages"; I would rather opt for keeping the French word: agencement. First, this term renders perceptible the intimate link between "agencement" and "agency," and second, it insists upon an active process of attunement that is never fixed once and for all. An agencement is a rapport of forces that makes some beings capable of making other beings capable, in a plurivocal manner, in such a way that the agencement resists being dismembered, resists clear-cut distribution. What constitutes the agent and the patient is distributed and redistributed incessantly. This should draw one's attention to the fact that, referring to the Umwelt, Deleuze defines "concrete milieu" and "lived milieu"-milieu concret and milieu véc $u^{36}$ - as equivalent: these two terms refer to the "grasping" whose direction cannot be determined: on the one hand, the milieu "is taking" the animal: it affects it, it captures it, it effectuates its power to be affected; on the other hand, the milieu does not exist outside the "grasping" to which it is submitted: it exists through the way that a given animal confers on this milieu the power to affect it.

Agency is the product of this agencement; there is no agency without agencement. In other words, a being's agency testifies to the existence of an agencement. There is, in each agencement, co-animation, in the literal sense of the term, that is, in the most animist meaning of the term.

We can now also explore why, be it in Crist's example or in Hustak and Myers's narratives, agency seems so intimately linked to the existence of a world of sensuous experience-let us remember, for example, that Crist claims that the peacock was an "inhabitant of an aesthetic world." Of course, we may suggest as she does that acting for pleasure or amusement embeds an "experiential viewpoint." ${ }^{37}$ But this answer, as sound as it may be, does not suffice. The sensual experience is not solely an experiential perspective that one may infer, or even share from outside; it is not solely a perspective that grounds the very existence of a subject, the subject of this perspective. The sensual experience happens where living organisms touch one another, affect and are being affected by one another. We recognize a sensual experience as the concrete experience in which each of the "becoming-actors" effectuates in the others the power to be affected. A sensual experience is a flow of forces. These are the forces that attune, agence (instead of "assemble") the agencement, and these are the forces that enact and articulate agency.

"Force" is to be understood in terms of its power to affect other forces to which it is related, and to be affected by other forces in turn. Inciting, provoking, producing, inducing, arousing, sparking, evoking, instigating, engaging, inspiring, and so on are examples of active affects inside an agencement; a reactive affect is understood in terms of the capacity to be incited, inspired, engaged, or provoked, or in being induced to produce - or even in terms of the power to give another being the power to affect you: what Latour has designed as the "faire faire," meaning in French "to make one do" and "causing to be done." 38

36. Ibid., 51.

37. Crist, Images of Animals, 36.

38. Bruno Latour, "Factures/Fractures: From the Concept of Network to the Concept of Artachment,", Res 36 (Autumn 1999), 20-31. 
As there is no way to touch without being touched, there is no way to determine who touches whom. Touching enacts a desubjectification. One may now be an agent without being a subject; one is nevertheless not an object. Being a subject is only one of the possible ends of the process - it may be the end that closes the story. As Deleuze and Felix Guattari wrote in A Thousand Plateaus, "it is dangerous to confine oneself to such a subject, which does not function without drying up a spring or stopping a flow." ${ }^{39}$ That is why I suggest that Hustak and Myers's narratives not only challenge bodily and species boundaries, but also subject/agent boundaries. Deleuze and Guattari claimed:

We believe that the third person indefinite, HE, THEY, implies no indetermination from this point of view; it ties the statement to a collective agencement, as its necessary condition, rather than to a subject of the enunciation. Blanchot is correct in saying that ONE and $\mathrm{HE}$ - one is dying, he is unhappy - in no way take the place of a subject, but instead do away with any subject in favor of an agencement of the haecceity type ${ }^{40}$ that carries or brings out the event insofar as it is unformed and incapable of being effectuated by persons ("something happens to them that they can only get a grip on again by letting go of their ability to say 'I'"). The HE does not represent a subject but rather makes a diagram of an agencement. It does not overcode statements, it does not transcend them as do the first two persons; on the contrary, it prevents them from falling under the tyranny of subjective or signifying constellations, under the regime of empty redundancies. ${ }^{41}$

We are, in some ways, getting close to what the anthropologist of art Alfred Gell proposes as a conception of agency when he defines objects of art as social agents and artistic productions as "objects mediating social agency." 42 Art-likesituations, Gell explains, are those in which the material index (the visible thing) permits the abduction of social agency - abduction being an inference that allows

39. Deleuze and Guattari, A Thousand Plateaus, 276.

40. "Haecceity" is a medieval term that denotes the discrete qualities, properties, or characteristics of a thing that make it a particular thing. Haecceity is a person or object's "thisness." Nikolas Rose writes (and makes clearer): "we can act upon ourselves to inhabit such nonsubjectified forms of existence. These nonsubjectified forms [are what] they term 'haeccities'-modes of individualization that are not those of a substance, a person, a thing, or a subject but a cloud, a winter, an hour, a date. ... ." Nikolas Rose, Inventing Our Selves: Psychology, Power, and Personhood (Cambridge, UK: Cambridge University Press, 1998), 170.

41. Deleuze and Guattari, A Thousand Plateaus, 264-265. Translation modified.

42. Alfred Gell, Art and Agency: An Anthropological Theory (Oxford: Clarendon Press, 1998), 7. To resituate Gell's problem: anthropology is a social discipline that aims to study social relationships; it is not the discipline that aims to study culture. Anthropology of art, therefore, should not be what history of art seeks to do-that is, "to recapture the 'way of seeing' which artists of [a given] period implicitly assumed their public would bring to the period" (2). The elucidation of non-Western aesthetic systems does not constitute an "anthropology of art," which is a cultural not a social program. "The anthropology of law, for instance, is not the study of legal-ethical principles - other peoples' ideas of right and wrong - but of disputes and their resolutions, in the course of which disputants do often appeal to such principles. Similarly, the anthropology of art cannot be the study of the aesthetic principles of this or that culture, but of the mobilization of aesthetic principles (or something like them) in the course of social interaction" (4). This leads Gell to view art as a system of actions, intended to change the world rather than encode symbolic propositions about it. He takes as an example a warrior's shield: the design is not to be seen on a battlefield by the opponent warrior as an aesthetic object: it is indisputably "a work of art of the kind interesting to the anthropologist, but its aesthetic properties (for us) are totally irrelevant to its anthropological implications. Anthropologically, it is not a 'beautiful' shield, but a fear-inducing shield. The innumerable shades of social emotional responses to artifacts (of terror, desire, awe, fascination, etc.) in the unfolding patterns of social life cannot be encompassed or reduced to aesthetic feelings ..." (6). 
the sign to acquire its meaning; or it is, according to Pascal Boyer, "induction in the service of explanation." 43 In this context, the art object has the peculiarity of being seen as the outcome and/or the instrument of social agency. Gell adds that his theory is not concerned with philosophical theory, which presupposes the autonomy and self-sufficiency of the human agent, ${ }^{44}$ but rather with the kind of agency artifacts acquire in conjunction with specific associates, "once they become enmeshed in a texture of social relationships." ${ }^{45}$

Gell explores at great length all the situations where one may see each of the agents (art object, prototype, artist, patron) exchanging positions with one another, sometimes being patients vis-à-vis the others becoming agents, sometimes agents vis-à-vis the others becoming patients, sometimes both. I would suggest, even if he does not use the word very often (but he does), that Gell is in fact talking in terms of "responsibility." This word is neither, in his work, merely a causal term, nor is it used in an intentional sense, but it appears in the (large) sense of responding, and being "responsible": in a sense that may be very similar to the one Etienne Souriau used to designate the responsibility of the artist to "respond" to the requirements and demands of the "oeuvre à faire," the oeuvre that calls for its coming into existence and into achievement. According to Souriau, the oeuvres are real beings, but whose existence demands promotion on other planes. They lack existence, be it only because they enjoy only a physical existence. The oeuvre, in other words, appeals for its fulfillment in another mode of existence. As Latour comments: "Everywhere, building, creating, constructing, laboring means to learn how to become sensitive to the contrary requirements, to the exigencies, to the pressures of conflicting agencies where none of them is really in command. Especially not the 'maker' who spends nights and days trying to live up to his or her responsibility to what Etienne Souriau has magnificently called instauration, or 'l' $œ u v r e$ à faire.",46

Agency, therefore, appears clearly as the capacity not only to make others do things, but to incite, inspire, or ask them to do things. This is how oeuvres or divinities achieve their existence and acquire agency in turn. This is how flowers gain agency, through becoming enabled to make their companion pollinators be moved by them, and this is how the latter could themselves be agents, through becoming enabled to make the flowers able to attract them, and in turn to be moved by them. This is why agency always appears in a flow of forces. Agencies spring in a flow of forces, in agencements that make more agencies: the one who

43. Ibid., 13-14.

44. He, however, distinguishes a category of agents that are "self-sufficient" and autonomouslike humans - and secondary agents, which are agents in conjunction with certain specific (human) associates (ibid., 17). I radically disagree with this distinction insofar as I do not know (and have never met) a "self-sufficient" and autonomous agent. This distinction considerably weakens Gell's proposition and appears contradictory to his very original and interesting speculation. As my aim is not to discuss this author, but to seek in his work the resources to help us with "secret agent," I am not going to argue this point further (contenting myself with honestly signaling it: Gell, if he were still alive, probably wouldn't follow me all the way in my development of these issues).

45. Ibid.

46. Latour, "The Promises of Constructivism," in Chasing Technology: Matrix of Materiality, ed. Don Ihde. Indiana Series for the Philosophy of Science (Bloomington: Indiana University Press, 2003), 27-46. http://www.bruno-latour.fr/node/166 (accessed September 7, 2013). 
makes other do, the one who makes others move, the one who inspires others to be inspired, and the one who is therefore induced, mobilized, and moreover, put in motion, activated.

Returning to Gell's patient/agent dichotomy: in his perspective, this is not a contradictory scheme along the passive/active dichotomy. Not only may each agent be a patient, but, on the one hand, the "sphere of activity" and the "sphere of vulnerability" may overlap, and on the other hand, still according to Gell, "it is important to understand, though, that 'patients' in agent/patient interactions are not entirely passive; they may resist. The concept of agency implies the overcoming of resistance, difficulty, inertia, etc." ${ }^{47}$

Regarding resistance, I have wondered recently (all the more after reading some of the articles in this issue) why, when animals "resist," their very resistance seems to operate as a vector of agency. Of course, protesting, refusing, cheating, ${ }^{48}$ and resisting may be linked to the existence of an "experiential viewpoint." This is particularly the case in the work of Baratay, whom I mentioned earlier. I noticed in Baratay's book that the author's purpose (to seek the conditions of an animal's perspective) was all the more convincing, and the attempt was best achieved, when Baratay evoked "working animals," especially horses in mines. Of course, as the French sociologist Jocelyne Porcher claims-referring to Haraway - "work is a particularly fertile element of 'natureculture,' which facilitates humans' entry into the world of animals and vice versa." ${ }^{49}$ But this is not the sole reason: in Baratay's description, working animals resist. This very resistance not only conveys their perspective on the situation but credits them with full agency: they have opinions, will, desires, and interests. ${ }^{50}$ I would suggest, in that vein, that Grandin ${ }^{51}$ renders the animals she observes much more interesting, more active, more present, and more eloquent not only because she may share their point of view, but because she meets them in the specific situation where they resist. They are entangled in a rapport of forces..$^{52}$

47. Gell, Art and Agency, 23. He adds: "Art objects are characteristically 'difficult.' They are difficult to make, difficult to 'think,' difficult to transact. They fascinate, compel, and entrap as well as delight the spectator. Their peculiarity, intransigence, and oddness is a key factor in their efficacy as social instruments."

48. Cheating might be the most salient clue in favor of this "experiential viewpoint," all the more since, as cognitive ethologists claim, cheating (deceiving) rests upon the possibility of adopting another being's perspective. In other words, an animal who uses a deception tactic most of the time needs to understand the minds and beliefs of another individual in order to deceive it, that is, the animal is able to adopt others' viewpoints. See, for example, David Premack and George Woodruff, "Does the Chimpanzee Have a Theory of Mind ?" Behavioral and Brain Sciences 4 (1978), 516-526; see also, for a very good review, Lucy Bates and Richard Byrne, "Creative or Created: Using Anecdotes to Investigate Animal Cognition," Methods 42 (2007), 12-21.

49. Jocelyne Porcher and Tiphaine Schmitt, "Dairy Cows: Workers in the Shadows?," Society \& Animals 20, no. 1 (2012), 39-60; emphasis mine. See also J. Porcher, Vivre avec les animaux: Une utopie pour le XXIe siècle (Paris: La Découverte, 2011), and V. Despret and Jocelyne Porcher, Etre Bêt (Arles: Actes Sud, 2007).

50. It is interesting to note here the description that Porcher, inspired by the French psychoanalyst Christophe Dejours, gives of "work": "the power of work is threefold: transforming the world, objectifying intelligence, and producing subjectivity. The subjective relation to work represents a fundamental relationship to life" (Porcher and Schmitt, "Dairy Cows," 43).

51. See Fudge's article in this issue.

52. Even Grandin is entangled in this rapport of forces, since she has to act with (and upon) this resistance. She herself becomes an agent through her encounters with cattle. Her depiction of these 
Porcher in fact explicitly and experimentally put this hypothesis to the test. She claims that breeding animals are actively involved in the work with their breeders; they are working. But we don't see them doing it. They take initiative; they actively engage themselves in order to help their breeder-but no one recognizes it. "Cows do more than simply function; they invest their intelligence and their affects in the work." 53 Porcher and one of her students, Tiphaine Schmitt, spent a long time observing and filming the cows in one particular herd kept in a barn. They noted all the occasions on which the cows had to act on their own initiative, follow rules, and work cooperatively with the breeder, anticipating his actions so that he could finish his work. They also paid attention to the strategies the cows created to maintain a peaceful environment, the polite maneuvers, the social grooming, and placatory gestures of the cows, such as giving way to a fellow, letting another take one's place, and so on.

What Porcher and Schmitt observed is exactly the reason why work is invisible: the cows' work never becomes perceptible, except when they refuse to cooperate, place limits on what can happen, explicitly disobey, pretend not to understand, hide themselves, cheat, or when, for example, they deliberately try to slow down the pace and seek places or opportunities to avoid work: when they resist. This resistance shows that when everything goes correctly, it is because of an active investment on the part of the cows. As in the case of human work, animals' collaboration at work is visible when it is not obtained.

When everything happens as it should, we don't see the work. As in Baratay's account, we see clearly that the conditions under which the animals' agency appears are the conditions in which the animals show that they can resist, that they can throw their heads in refusal, even sabotage the work and its possibilities. We find again, implicitly, this very condition in the testimony of animal technicians working on scientific experiments: if the animals will not cooperate, there can't be an experiment..$^{54}$ Thus, on the contrary, when the cows go peacefully to be attached to the milking machine, when they do not kick up a fuss, when they go in order, when they take one another into account, when they move away from the machine after the milker has finished, when they move here and there to allow the breeder to clean their stalls, when they do what has to be done in

situations itself creates this rapport, creating the agencement and being part of it. This allows me not to differentiate, as historians could be constrained to do, between descriptions of situations in the past and current depictions. Of course, Hustak and Myers's interventions, for example, are to a great extent carried by Darwin's descriptions: which descriptions are warranted might be a more problematic issue for historians (see, again, Fudge's article). But since I do consider Hustak and Myers's analysis to be actively part of the agencement, the agencement itself would be dismembered should I attempt to disentangle Darwin's depictions from what these two historians do with them.

53. Porcher and Schmitt, "Dairy Cows," 55.

54. See also Robert Kirk's beautiful paper about Michael Robin Chance: "Between the Clinic and the Laboratory: Ethology and Pharmacology in the Work of Michael Robin Alexander Chance, $c$. 1946-1964, " Medical History 53, no. 4 (2009), 513-536: the article discusses "[t]he importance of ethology to Chance's experimental science . . ., with particular focus upon how ethology imbued the laboratory animal with subjective 'natural' characteristics, feelings, and needs. Consequently, Chance reconfigured the relationship between experimenter and experimental animal as one based on mutual obligation and co-operation. This ... [has] opened up a new territory within which the explicit recognition of an ethical relationship between researcher and laboratory animal became a necessary part of experimental practice" (513; emphasis mine). 
response to an order, when they do what they must so that everything happens as it is supposed to, we do not see this as testimony to their willingness to do what is expected of them.

However (I will probably push this point slightly too far), I would even suggest that what we call mechanistic thought, ironically, could be partially due to the good will of the animals themselves! When animals do what they know is expected of them, everything begins to look like a machine that is functioning, and their obedience looks "mechanical," a word that conveys its meaning very well. ${ }^{55}$

I love, by contrast, this story Vicki Hearne tells about cats in an experimental setting. She heard some older experimenters advising younger ones, saying that cats are generally fairly good at the beginning of the procedure, but, they add, things generally go wrong after the first test procedures. If you give cats a problem to solve or a task to perform in order to find food, they work it out pretty quickly, and the graph of their comparative intelligence shows a sharply rising line. But the older experimenters then say (although they will never publish on this subject): "the trouble is that as soon as they figure out that the researcher or technician wants them to push the lever, they stop doing it; some of them will starve to death rather than do it." ${ }^{56}$ Hearne suggests "the refusal of food is a signal made to the cosmos itself when one despairs of signaling one's chums that something deep in nature is denied." Cats, she says, cannot tolerate situations in which there is only one choice, that of responding in a linear way to human expectations, a kind of "pleasing" that is in fact in violation of the cat's nature. And this is the case because "the pleasures and expectations of human beings are profoundly important to cats." 57

"Secret agents," as David Gary Shaw named them (how true this is in Porcher's survey!) ${ }^{58}$ become subjects through resistance. It is therefore not fortuitous that the search for "perspective," in Fudge's article, takes this very shape: she shows very convincing examples of cows "resisting" to elucidate what is to be a cow in the seventeenth century. Also, we are reminded that some animals have routines, and that these routines are made clearer by contrast when the routine is broken.

55. But we may also suggest that the way work is organized does not bring to the fore animals' actual opportunities to act in a nonmechanical way, as Porcher quoting Christophe Dejours, writes: "Being intelligent in work always means standing back from procedures and instructions. Working well implies violating recommendations, regulations, procedures, codes, specifications and normative organization. In many work situations, however, the monitoring and surveillance of gestures, movements, operating methods, and procedures are rigorous if not severe, with the result that intelligence in work is often condemned to remaining unobtrusive, or even hidden" (Porcher and Schmitt, "Dairy Cows," 43). I would add that in that case, humans as well as animals are "secret agents."

56. In human psychology, such a thing could scarcely happen: most of us respect academic authority and will work out the problem for "the sake of science." Maybe we should suggest that human beings are less well equipped for agency than animals in experimental settings (see V. Despret, Our Emotional Makeup: Ethnopsychology and Selfhood [New York: Other Press, 2004)]).

57. Vicki Hearne, Adam's Task: Calling Animals by Name [1986] (New York: Skyhorse Publishing, 2007), 225-226.

58. David Gary Shaw, "The Torturer's Horse: Agency and Animals in History," History and Theory, Theme Issue 52 (December 2013), 146-167. 
From all these testimonies, I would suggest that an animal resisting indeed appears as the very subject of the action, but it is not the same process as the one by which he/she becomes an agent. "Agenting" (as well as "acting") is a relational verb that connects and articulates narratives (and needs "articulations"), beings of different species, things, and contexts. There is no agency that is not interagency. There is no agency without agencement, a rapport of forces.

Resisting is not reacting, but open responding embedded in a cascade of "faire faire," "making to do," which is open to surprise and which testifies to the active involvement of the beings in (and creating) the agencement. In moments of resistance, spheres of vulnerability and spheres of activity overlap and make salient the intimate co-involvement of the creatures that are engaging one another in an ever-new story. They become "companion-agents" through encounters, conflicts, collaborations, frictions, affinities - a rapport of forces.

Agency is not independence: one of the readings I would feel inclined to give to Shaw's article would, to conclude, be this: the issue is not about seeking independent existences but about inquiring about the multiple ways one given creature depends on other beings. To be an agent requires dependency upon many other beings; being autonomous means being pluri-hetero-nomous. We are all secret agents, depending on the circumstances, waiting for another being who will give us new agencies, new ways of becoming agents, actively acted upon, undoing and redoing precarious selves (through) one another.$^{59}$ This is, since the beginning of our time as living creatures, our history: a history that needs new stories, for these can be given a sequel.

\section{Université de Liège}

59. As Latour, who deeply inspired this paper, beautifully wrote: "To be a subject is not to act autonomously in front of an objective background but to share agency with other subjects that have also lost their autonomy." "Which Language Shall We Speak with Gaia?"; author's emphasis. 